\title{
Podophyllotoxin Content and Yield of American Mayapple Leaves in Sun and Shade
}

\author{
Kent E. Cushman ${ }^{1}$ and Muhammad Maqbool \\ Southwest Florida Research and Education Center, 2686 SR 29 North, \\ Immokalee, FL 34142
}

\author{
Hemant Lata, Ebru Bedir, Ikhlas A. Khan, and Rita M. Moraes \\ National CenterforNatural Products Research, Thad Cochran Research Center, \\ School of Pharmacy, University of Mississippi, University, MS 38677
}

Additional index words. Podophyllum peltatum, podophyllotoxin, peltatin, lignan, medicinal herb, alternative crop

\begin{abstract}
Four levels of shade $(0 \%, 30 \%, 55 \%$, and $80 \%)$ were used to determine their effect on growth and lignan content of american mayapple (Podophyllum peltatum L.). Mayapple rhizomes were harvested from the wild and transplanted into plant beds on 20 Dec. 2001 using a randomized complete block design with four blocks. Growth and lignan content were recorded during spring of 2002 and 2003 . Leaf samples were analyzed for the following lignans: podophyllotoxin, alpha-peltatin, and beta-peltatin. Increasing levels of shade increased shoot longevity, leaf area per plant $\left(\mathrm{cm}^{2} /\right.$ plant $)$, and shoot height. Shade did not affect shoot emergence, total leaf area $\left(\mathrm{cm}^{2} \cdot \mathrm{m}^{-2}\right)$, or leaf dry mass $\left(\mathrm{g} \cdot \mathrm{m}^{-2}\right.$ or $\mathrm{g} /$ plant $)$. Regardless of year, podophyllotoxin and total lignan contents at $0 \%$ shade were significantly greater than those at $80 \%$ shade, and the overall trend was for decreasing contents with increasing shade. Shade did not affect alpha-peltatin content. Content of beta-peltatin was greatest at $0 \%$ shade compared to the other three shade treatments. Year affected alpha-peltatin and beta-peltatin contents, with less content of each in 2003 than in 2002. There were large numerical decreases in podo-

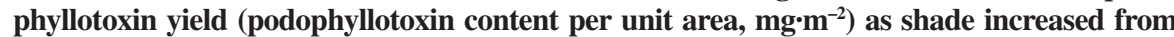
$0 \%$ to $80 \%$, but these differences were only marginally significant $(P=0.0897)$. In contrast, podophyllotoxin yield was significantly greater in 2003 than in 2002 as total leaf area and dry mass significantly increased. Increasing levels of shade slightly decreased air and soil temperatures. Our results indicate that american mayapple is not a shade-requiring species. Under full sun ( $0 \%$ shade) shoots did not persist as long as under shade and leaves were smaller and thicker, but total lignan content was significantly greater than under shade. It appears that growers of specialty crops serving the pharmaceutical industry can establish and cultivate american mayapple under full sun, thus providing leaf biomass with high podophyllotoxin content while avoiding the cost of expensive shade structures.
\end{abstract}

The american mayapple (Podophyllum peltatum L.) is a medicinal plant of interest to the pharmaceutical industry because it contains podophyllotoxin, a lignan used as a precursor in the manufacture of several types of pharmaceuticals (Bedows and Hatfield, 1982; Canel et al., 2000a; Jackson and Dewick, 1985; Lerndal and Svensson, 2000). Currently, the commercial source of podophyllotoxin is extracted from roots and rhizomes of the Indian mayapple, $P$. emodi Wall (syn. P. hexandrum Royle). However, destructive harvest and over-exploitation of this species has lead to its status as an endangered species (Foster, 1993; Rai et al., 2000). Leaves of american mayapple were reported to contain relatively high levels of podophyllotoxin and the plant has potential as an alternative and

Received for publication 28 June 2004. Accepted for publication 7Aug. 2004. This research was supported by NRI Competitive Grant Program 71.2, Award 2002-01525, and Specific Cooperative Agreement 58-6408-7-012. Approved for publication as Journal article J-10547 of the Mississippi Agricultural \& Forestry Experiment Station, Mississippi State University.

${ }^{1}$ To who reprint requests should be addressed; kecushman@ifas.ufl.edu. spring and appear to take advantage of mottled sunlight under trees not yet in full foliage. The plant grows in colonies and is most often seen in wooded areas. Though uncommon, colonies can be found thriving in full sun. Medicinal plants that grow in similar wooded environments as mayapple have been shown to require shade. In Canada and several northern states of the U.S., a mature horticulture industry exists around the production of american ginseng (Panax quinquefolium L.) (Craker et al., 2003; Persons, 1994). The standard production practice is to grow ginseng under $70 \%$ to $80 \%$ shade at a cost of about $\$ 12,000$ to $\$ 16,000$ (\$US) per acre (Schooley, 2003). Goldenseal (Hydrastis canadensis L.) is a shade-requiring species that can be grown in rotations with ginseng (Davis and McCoy, 2000; Sinclair and Catling, 2001). In every aspect of growth that was measured it performed better under moderate shade (60\% to $70 \%$ ) than under extreme shade $(95 \%)$. In addition, foliage of control plants under full sun was scorched and severely stunted (Quigley and Mulhall, 2002). Though there are few guides to the cultivation of black cohosh [Actaea racemosa L., syn. Cimicifuga racemosa (L.) Nutt.], it is described as growing in the wild in areas of deep shade (Foster, 2000). Nurseries that sell black cohosh to the public often suggest planting in part to full shade, though some nurseries recommend planting in part shade to full sun.

The purpose of this research was to determine the effects of shade on growth and lignan content of shoots arising from mayapple rhizome segments transplanted from the wild and grown under cultivation. This research is part of a larger effort to explore the domestication of american mayapple for its podophyllotoxin content and for its potential interest to growers of specialty crops (Moraes et al., 2000).

\section{Materials and Methods}

Mayapple rhizome segments were harvested from the wild near Oxford, Miss. $\left(34.372^{\circ} \mathrm{N}, 89.541^{\circ} \mathrm{W}\right.$, elevation $\left.100 \mathrm{~m}\right)$ on 19 Dec. 2001. The site was a mixed mesophytic habitat that appeared not to have been disturbed in the past 20 to 30 years as judged by the age its trees. Plants were dormant at this time of year and rhizomes were located by carefully removing leaf litter and a shallow layer of soil in a location known to have mayapples. Segments were severed from the larger rhizome

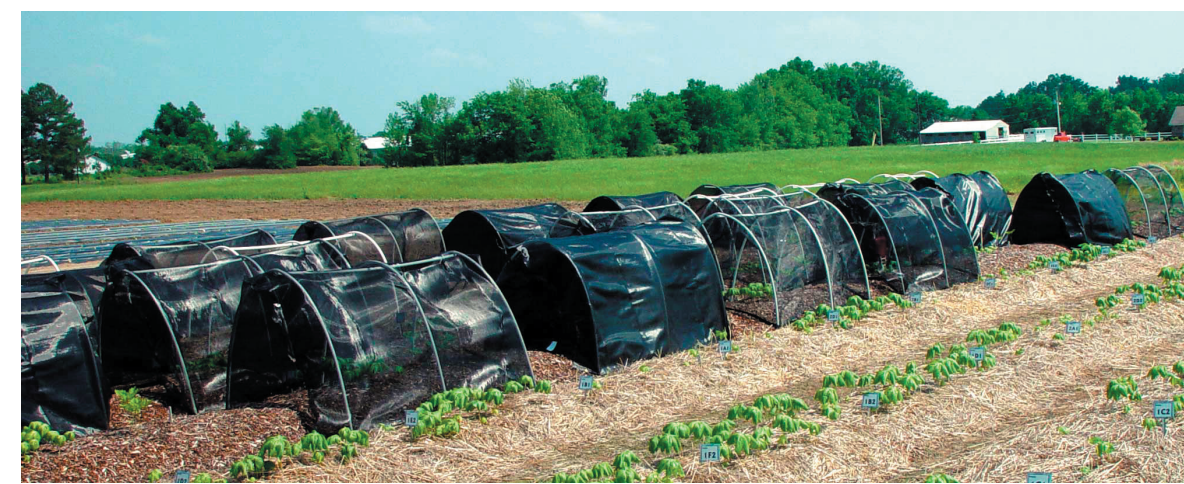

Fig. 1. Shade structures and field layout used in this study. 


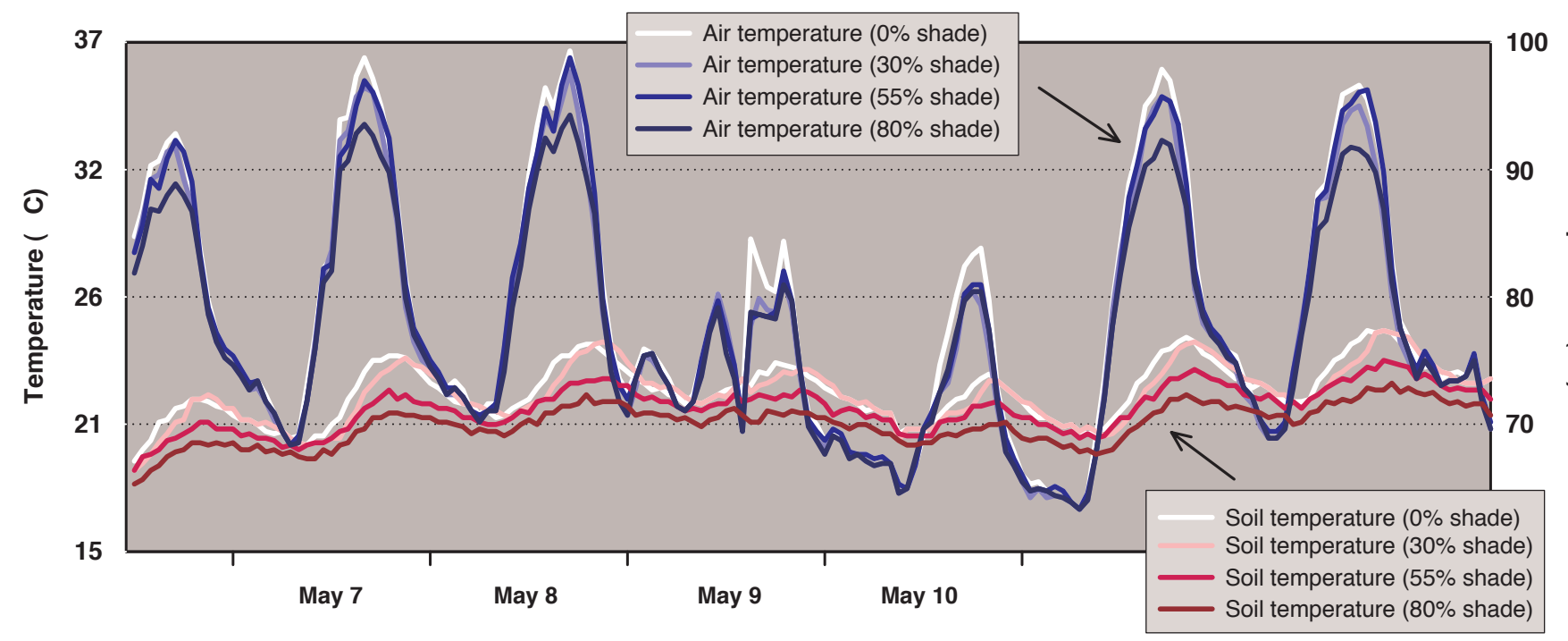

Fig. 2. Example of the effect of four shade (sunlight exclusion) treatments on air and soil temperatures during growth of american mayapple shoots. Shown is period of 6 to 12 May 2002. Treatments were $0 \%, 30 \%, 55 \%$, and $80 \%$ shade. Mayapple rhizome segments were planted in Fall 2001 and shoots emerged during spring of 2002 and 2003. Thermocouples were placed at the depth of rhizome planting, about $1.3 \mathrm{~cm}$, for soil temperatures and $15 \mathrm{~cm}$ above the mulched surface for air temperatures.

system to which they were attached and then carefully removed with roots intact. Soil adhering to the rhizomes was gently shaken loose. Each segment consisted of two nodes, a terminal node and a 1-year-old node, connected by internodal tissue (referred to as propagule type Nt+N1 in Maqbool et al., 2004). Rhizomes were separated into four groups based on size and apparent vigor: small, medium, large, and extra large. Length of rhizome segments ranged from 5 to $7.5 \mathrm{~cm}$ for small-sized rhizomes to 18 to $20 \mathrm{~cm}$ for extra-large-sized rhizomes. The diameter of internodal tissue of each group followed a similar trend, with smallsized rhizomes having the smallest diameter and extra-large rhizomes having the largest diameter. Rhizomes were then transplanted into a randomized complete block design with four blocks, with extra-large rhizomes transplanted to block 1, large rhizomes to block 2, and so on. Rhizomes were transplanted to raised beds at the Horticulture Research \& Education Unit at Verona, Miss., on 20 Dec. 2001. Raised beds were prepared with a press-pan-type bed shaper and spaced $1.8 \mathrm{~m}$ apart, center to center. Beds were formed $15 \mathrm{~cm}$ high and $75 \mathrm{~cm}$ wide across the top and drip irrigation tubing was installed in the middle of the bed. Each experimental unit (plot) consisted of 20 rhizome segments arranged in four parallel rows with each row spaced $15 \mathrm{~cm}$ apart across the top of the raised bed. Within each row, five rhizomes were planted $15 \mathrm{~cm}$ apart and about $1.3 \mathrm{~cm}$ deep. Plots were immediately covered with a $2.5 \mathrm{~cm}$ layer of finely milled pine bark mulch (particle size 0 to $1.0 \mathrm{~cm}$ ) and then an additional $5 \mathrm{~cm}$ layer of coarse pine bark mulch (particle size 1.0 to $2.5 \mathrm{~cm}$ ). Plots were watered by hand immediately after transplant. The soil at Verona is a Quitman fine sandy loam (fine-loamy, siliceous, thermic, Aquic Paleudult).

Four levels of shade (sunlight exclusion) were used: $0 \%, 30 \%, 55 \%$, and $80 \%$. In 2002, the $30 \%, 55 \%$, and $80 \%$ shade treatments were installed 27 Mar., a time when mayapple shoots were emerging from the ground. In 2003, shade treatments were installed 30 Jan., a time one month prior to shoot emergence. Treatments were installed before shoot emergence during the 2003 season to account for the influence of shade on soil temperatures and its possible effect on time of emergence. Shade material was removed from the frames to which they were attached after all mayapple shoots had senesced completely each year. Thus, shade treatments were in place for about five to six months of each year. Frames were constructed of 1.9-cm-diameter polyvinylchloride tubing and bent into hoops over each plot. Frames were $3.0 \mathrm{~m}$ long, $1.5 \mathrm{~m}$ wide, and stood about $1.5 \mathrm{~m}$ at the highest point. Black polypropylene shade material with a lath weave design (Hummert Intl., Earth City, Mo.) was placed over and attached to each frame. Shade material covered the entire surface of the structure, including ends, and extended to the soil surface (Fig. 1). Rainfall was adequate to above adequate during each spring, but during early summer drip irrigation was applied as needed to keep beds moist but not wet. A data logger (model 7000B; Starlog Macro, Unidata America, Lake Oswego, Ore.) was installed 2 Apr. 2002 and again 30 Jan. 2003 to record air and soil temperatures in one replication of each treatment. Air temperature was recorded $15 \mathrm{~cm}$ above the mulched surface and soil temperatures were measured at the rhizome planting depth, about $1.3 \mathrm{~cm}$. Each year, sporadic performance of the data logger resulted in an incomplete record of air or soil temperatures. Photosynthetic photon flux (PPF) was measured with a LI-COR light sensor (LI-190; LI-COR, Lincoln, Nebr.) on 9 June 2003 on a cloudless, sunny day to confirm that target levels of sunlight exclusion had been achieved. PPF was measured twice, one hour before and one hour after 12:00 PM.

Weeds that had established during winter were killed with glyphosate $\left(4.5 \mathrm{~kg} \cdot \mathrm{ha}^{-1}\right)$ applied 17 Feb. 2002 and 28 Feb. 2003 before mayapple shoots had emerged. Weeds that had established during spring were not controlled as long as mayapple plants were emerging,

Table 1. Shoot emergence, shoot longevity, leaf area, leaf dry mass, and shoot height as influenced by shade and year after establishing american mayapple in field plantings in 2001. Data recorded spring of 2002 and 2003.

\begin{tabular}{|c|c|c|c|c|c|c|c|c|}
\hline $\begin{array}{l}\text { Shade } \\
(\%)\end{array}$ & Year & $\begin{array}{c}\text { Avg } \\
\text { shoot } \\
\text { emergence } \\
\left(\text { shoots } / \mathrm{m}^{2}\right)\end{array}$ & $\begin{array}{c}\text { Avg } \\
\text { shoot } \\
\text { longevity } \\
\text { (days) }\end{array}$ & $\begin{array}{c}\text { Total } \\
\text { leaf } \\
\text { area } \\
\left(\mathrm{cm}^{2} \cdot \mathrm{m}^{-2}\right)\end{array}$ & $\begin{array}{c}\text { Plant } \\
\text { leaf } \\
\text { area } \\
\left(\mathrm{cm}^{2} / \mathrm{shoot}\right)\end{array}$ & $\begin{array}{c}\text { Total } \\
\text { leaf } \\
\text { dry mass } \\
\left(\mathrm{g} \cdot \mathrm{m}^{-2}\right)\end{array}$ & $\begin{array}{c}\text { Plant } \\
\text { leaf } \\
\text { dry mass } \\
\text { (g/shoot) }\end{array}$ & $\begin{array}{l}\text { Avg } \\
\text { shoot } \\
\text { ht }^{y} \\
(\mathrm{~cm})\end{array}$ \\
\hline 0 & & 41.4 & $51.0 \mathrm{c}^{\mathrm{z}}$ & 5,460 & $133 \mathrm{c}$ & 20.8 & 0.51 & $14.2 \mathrm{c}$ \\
\hline 30 & & 45.0 & $58.5 \mathrm{c}$ & 7,770 & $171 \mathrm{bc}$ & 27.8 & 0.61 & $17.1 \mathrm{~b}$ \\
\hline 55 & & 49.7 & $65.6 \mathrm{~b}$ & 9,900 & $190 \mathrm{ab}$ & 33.0 & 0.63 & $18.8 \mathrm{~b}$ \\
\hline 80 & & 45.1 & $80.5 \mathrm{a}$ & 10,200 & $221 \mathrm{a}$ & 31.1 & 0.67 & $22.2 \mathrm{a}$ \\
\hline & 2002 & 43.5 & $67.3 \mathrm{a}$ & $5,860 \mathrm{~b}$ & $134 \mathrm{~b}$ & $19.2 \mathrm{~b}$ & $0.44 \mathrm{~b}$ & --- \\
\hline & 2003 & 47.1 & $60.5 \mathrm{~b}$ & $10,830 \mathrm{a}$ & $223 \mathrm{a}$ & $37.2 \mathrm{a}$ & $0.77 \mathrm{a}$ & --- \\
\hline \multicolumn{9}{|l|}{$P$ value } \\
\hline Shade & & 0.4850 & $<0.0001$ & 0.0720 & 0.0084 & 0.2225 & 0.1118 & 0.0002 \\
\hline Year & & 0.3420 & 0.0135 & 0.0015 & $<0.0001$ & 0.0008 & $<0.0001$ & --- \\
\hline Shade $\times$ year & & 0.4870 & 0.7703 & 0.3198 & 0.1695 & 0.4594 & 0.3288 & --- \\
\hline
\end{tabular}

${ }^{z}$ Values in columns followed by the same letter are not significantly different at $P \leq 0.05$. Values are least square means of at least four replications.

${ }^{y}$ Shoot height recorded in 2003 only. 
Table 2. Podophyllotoxin, alpha-peltatin, beta-peltatin, total lignans, and podophyllotoxin yield as influenced by shade and year after establishing american mayapple in field plantings in 2001. Data recorded spring of 2002 and 2003.

\begin{tabular}{|c|c|c|c|c|c|c|}
\hline $\begin{array}{l}\text { Shade } \\
(\%)\end{array}$ & Year & $\begin{array}{c}\text { Podophyllo- } \\
\text { toxin } \\
\left(\mathrm{mg} \cdot \mathrm{g}^{-1}\right)\end{array}$ & $\begin{array}{l}\text { Alpha- } \\
\text { peltatin } \\
\left(\mathrm{mg} \cdot \mathrm{g}^{-1}\right)\end{array}$ & $\begin{array}{l}\text { Beta- } \\
\text { peltatin } \\
\left(\mathrm{mg} \cdot \mathrm{g}^{-1}\right)\end{array}$ & $\begin{array}{c}\text { Total } \\
\text { lignan } \\
\left(\mathrm{mg} \cdot \mathrm{g}^{-1}\right)\end{array}$ & $\begin{array}{l}\text { Podophyllo- } \\
\text { toxin yield } \\
\left(\mathrm{mg} \cdot \mathrm{m}^{-2}\right)\end{array}$ \\
\hline 0 & & & 2.98 & $0.42 \mathrm{a}^{\mathrm{z}}$ & & 498 \\
\hline 30 & & & 2.80 & $0.29 \mathrm{~b}$ & & 461 \\
\hline 55 & & & 2.73 & $0.25 \mathrm{~b}$ & & 382 \\
\hline \multirow[t]{3}{*}{80} & & & 2.66 & $0.24 \mathrm{~b}$ & & 224 \\
\hline & 2002 & & $3.25 \mathrm{a}$ & $0.35 \mathrm{a}$ & & $196 \mathrm{~b}$ \\
\hline & 2003 & & $2.79 \mathrm{~b}$ & $0.25 \mathrm{~b}$ & & $587 \mathrm{a}$ \\
\hline \multirow[t]{2}{*}{0} & 2002 & $15.39 \mathrm{c}$ & & & $19.59 \mathrm{bc}$ & \\
\hline & 2003 & $30.58 \mathrm{a}$ & & & $33.90 \mathrm{a}$ & \\
\hline \multirow[t]{2}{*}{30} & 2002 & $8.60 \mathrm{def}$ & & & $11.97 \mathrm{def}$ & \\
\hline & 2003 & $20.13 \mathrm{~b}$ & & & $23.21 \mathrm{~b}$ & \\
\hline \multirow[t]{2}{*}{55} & 2002 & $12.36 \mathrm{~cd}$ & & & $15.68 \mathrm{~cd}$ & \\
\hline & 2003 & $11.20 \mathrm{cde}$ & & & $14.12 \mathrm{de}$ & \\
\hline \multirow[t]{2}{*}{80} & 2002 & $6.12 \mathrm{f}$ & & & $9.61 \mathrm{f}$ & \\
\hline & 2003 & 7.48 ef & & & 10.34 ef & \\
\hline \multicolumn{7}{|l|}{$P$ value } \\
\hline Shade & & $<0.0001$ & 0.1492 & 0.0001 & $<0.0001$ & 0.0897 \\
\hline Year & & $<0.0001$ & 0.0087 & $<0.0001$ & $<0.0001$ & 0.0001 \\
\hline Shade $\times$ year & & 0.0002 & 0.6420 & 0.0617 & 0.0002 & 0.2148 \\
\hline
\end{tabular}

${ }^{2}$ Values in columns followed by the same letter are not significantly different at $P \leq 0.05$. Values are least square means of at least four replications.

growing, or senescing. Instead, these weeds were killed with glyphosate applied at the same rate on 8 July 2002, 25 June 2003, and 10 Sept. 2003 after all mayapple shoots had senesced. This strategy of weed control was effective, and plots were almost weed-free from emergence to senescence of the mayapple shoots. Fertilization requirements of mayapple plantings are not known at present, but plantings were fertilized at a low rate of $22.4 \mathrm{~kg} \cdot \mathrm{ha}^{-1}(20 \mathrm{~N}-8.7 \mathrm{P}-16.6 \mathrm{~K})$ soluble fertilizer delivered through the irrigation tubing on 18 Apr. 2002, 25 Apr. 2002, and 2 Apr. 2003. Diazinon was applied at the rate of $2.2 \mathrm{~kg} \cdot \mathrm{ha}^{-1}$ on 28 Mar. 2002, 12 Mar. 2003, and 25 Mar. 2003 to control black cutworm (Agrotis ipsilon Hufnagel). Brodifacoum $0.005 \%$ rodent bait (d-CON, Reckitt \& Colman Inc., Wayne, N.J.) was used on several occasions to control voles (Microtus sp.).

Plant emergence was recorded two or three times per week during March and April of each year. In 2002, all leaves within a plot were harvested as soon as two to three leaves within the plot began to exhibit evidence of senescence (yellowing), from the third week of April to the last week of June. In 2003, individual leaves within each plot were harvested as soon as the leaf began to exhibit evidence of senescence, from the third week of April to the third week of July. Shoot height in 2003 was determined at harvest by individually measuring all shoots within each plot from the surface of the mulch layer to where the petiole attached to the underside of the leaf. Leaf area of harvested leaves was measured using an area meter (LI-3100; LI-COR). Leaves were then dried in a forced-air, constant-temperature oven (model 1380FM; VWR Scientific Products, Cornelius, Ore.) at $40{ }^{\circ} \mathrm{C}$ for $4 \mathrm{~d}$ and dry mass recorded. Samples were dried at a lower-than-normal temperature to preserve lignan content. Samples were then sent to the National Center for Natural Products Research at the University of Mississippi for extraction and quantification of lignan content. Podophyl- lotoxin, alpha-peltatin, and beta-peltatin were extracted and quantified according to Canel et al. (2000b). Total lignan content was calculated as the sum of podophyllotoxin, alpha-peltatin, and beta-peltatin contents. Podophyllotoxin yield was calculated by multiplying podophyllotoxin content by total leaf dry mass. Data were analyzed as a randomized complete block with shade levels as treatments and years as repeated measures. The Mixed procedure of SAS v. 8.2 was used for all analyses (SAS Institute Inc., Cary, N.C.).

\section{Results}

Average values of $0 \%, 30 \%, 56 \%$, and $83 \%$ shade (sunlight exclusion) were calculated from average readings (mean $\pm \mathrm{SE}$ ) of $1895 \pm 40,1324 \pm 25,829 \pm 20$, and $328 \pm 7$ $\mu \mathrm{mol} \cdot \mathrm{m}^{-2} \cdot \mathrm{s}^{-1} \mathrm{PPF}$, respectively. These results confirm that target values for each shade treatment were achieved within an average error of $3 \%$ or less.

Shade affected air and soil temperatures of mayapple plots (Fig. 2). Air temperatures of $0 \%$ shade were nearly always higher during the day than those of $80 \%$ shade. Air temperatures of $30 \%$ and $55 \%$ shade were generally intermediate between that of the $0 \%$ and $80 \%$ treatments. Soil temperatures of $0 \%$ shade were nearly always higher during day and night than those of $80 \%$ shade. Soil temperatures of $30 \%$ and $55 \%$ shade were generally intermediate between that of the $0 \%$ and $80 \%$ treatments. Season-long averages could not be calculated due to intermittent performance of the recording data logger.

Shade did not affect number of shoots that emerged each spring (Table 1). It was assumed that slightly lower soil temperatures under increasing levels of shade would increasingly delay shoot emergence; however, shade did not influence time of shoot emergence (2003 only; data not shown). In contrast, shade greatly affected time of shoot senescence. Increasing levels of shade above $30 \%$ resulted in increas- ing days of shoot longevity, with longevity at $80 \%$ shade being $38 \%$ greater in duration than longevity at $30 \%$ shade (Table 1 ). Shoot longevity was also affected by year. Shoots persisted an average of about 2 months each year, but shoots senesced an average of about 7 d earlier in 2003 than 2002.

Shade did not affect total leaf area $\left(\mathrm{cm}^{2} \cdot \mathrm{m}^{-2}\right)$ or leaf dry mass $\left(\mathrm{g} \cdot \mathrm{m}^{-2}\right.$ or $\left.\mathrm{g} / \mathrm{plant}\right)$ (Table 1$)$. However, shade affected leaf area when calculated on a per plant basis ( $\mathrm{cm}^{2} /$ plant). Increasing shade resulted in increasing leaf area per shoot, with $80 \%$ shade having $66 \%$ greater leaf area per plant than $0 \%$ shade. Increasing shade also resulted in increasing shoot height, with $80 \%$ shade having $56 \%$ taller shoots than $0 \%$ shade (Table 1). Shoot height was recorded in 2003 but not in 2002. Year affected most of the above-mentioned variables. Shoots produced $66 \%$ to $94 \%$ greater leaf area and dry mass, respectively, in 2003 than 2002 regardless of whether the data was calculated on a per area or per plant basis.

There was a significant interaction between shade and year for podophyllotoxin and total lignan contents (Table 2). Regardless of year, podophyllotoxin and total lignan contents at $0 \%$ shade were significantly greater than those at $80 \%$ shade, and the overall trend was for decreasing contents with increasing shade (Table 2). However, podophyllotoxin and total lignan contents in 2003 were significantly greater than those of 2002 at $0 \%$ or $30 \%$ shade. In contrast, podophyllotoxin and total lignan contents in 2003 were not significantly different from those of 2002 at $55 \%$ or $80 \%$ shade.

Shade did not affect alpha-peltatin content but significantly affected beta-peltatin content (Table 2). Content of beta-peltatin was greater at $0 \%$ shade compared to the other three shade treatments (Table 2). Year affected alpha-peltatin and beta-peltatin contents, with less content of each in 2003 than in 2002. There were large numerical decreases in podophyllotoxin yield as shade increased from $0 \%$ to $80 \%$, but these differences were only marginally significant $(P=0.0897)$. In contrast, podophyllotoxin yield was significantly greater in 2003 than in 2002 (Table 2).

\section{Discussion}

Increasing shade resulted in slightly decreasing air and soil temperatures, thus confounding the effects of shade alone. Given the design of this study, the effects of shade and temperature cannot be separated. In the discussion below, the term shade is used with this understanding.

Shade greatly affected plant growth. As expected, shoots growing under increasing levels of shade produced increasingly larger leaves and taller plants. The larger leaves, however, did not have greater leaf mass, and as a result, shade treatments did not affect total leaf mass. This indicates that shade did not affect yield of leaf material when measured as weight of leaf material per square meter of growing area. Increasing shade also resulted in increasing shoot longevity, with an $80 \%$ reduction in light levels resulting in a $38 \%$ increase in days 
of shoot longevity. These results indicate that shoots partially compensated for lower light levels with increased leaf size and delayed shoot senescence. Shade did not affect the number of shoots that emerged each spring; therefore, number of shoots remained relatively constant across treatments and years.

Year affected all aspects of plant growth except shoot emergence. Shoot longevity was greater by 1 week in 2002 compared to 2003 . This is likely due to differences in weather from year to year, but no attempt to correlate shoot growth with temperature, irradiance, or precipitation was made in this study. All other measures of plant growth were greater in 2003 than in 2002, indicating that rhizome segments planted in this study had established successfully and were producing shoots and rhizomes with increasing vigor.

Shade affected lignan contents, with increasing levels of shade generally decreasing podophyllotoxin and total lignan contents. Year also affected lignan content, but only as it interacted with shade. Podophyllotoxin and total lignan contents greatly increased from 2002 to 2003 at the $0 \%$ and $30 \%$ levels but not at the $55 \%$ and $80 \%$ levels. It is clear from these results, however, that regardless of year, podophyllotoxin and total lignan contents were greatest under $0 \%$ shade, lowest under $80 \%$ shade, and intermediate under $30 \%$ and $55 \%$ shade. Content of beta-peltatin was greatest under $0 \%$ shade but statistically similar for $30 \%, 55 \%$, and $80 \%$ treatments, indicating that shade affected beta-peltatin content to a lesser extent than that of podophyllotoxin content. Content of alpha-peltatin was not affected by shade. In contrast to podophyllotoxin content, alpha- and beta-peltatin contents significantly decreased from 2002 to 2003. Podophyllotoxin yield was only marginally affected by shade. However, with large increases in dry mass yield from 2002 to 2003 in combination with higher podophyllotoxin contents in two out of four shade treatments in 2003 than in 2002, podophyllotoxin yield was much greater in 2003 than in 2002.

There are a large number of physiological and ecological reports about the effects of shade on photosynthesis, leaf pigments, and anatomy (e.g., Demmig-Adams and Adams, 1992) but there are few reports of the effects of shade on secondary metabolites in medicinal plants. Kelsey and Vance (1992) surveyed two populations of Pacific yew (Taxus brevifolia Nutt) for two forms of taxane: taxol and cephalomannine. One population was in shade and the other in full sun, and each population consisted of 10 trees. Cephalomannine content of bark and leaves was significantly greater in shade than in sun. Taxol content of bark was also significantly greater in shade than in sun, but in contrast, taxol content of leaves was not affected by sun or shade. As with our results with american mayapple, the effect of shade on compounds within leaves of pacific yew depended on the particular compound under investigation.

In conclusion, the american mayapple appears to be a shade-tolerant species. It is able to grow and thrive in full sun, unlike american ginseng, goldenseal and, to some extent, black cohosh (Davis and McCoy, 2000; Foster, 2000; Persons, 1994). Though able to grow and thrive under full sun, the species also performs well under increasing levels of shade. Leaf size was smaller and shoot longevity greater under full sun compared to shade, but total leaf mass was not affected. Podophyllotoxin and total lignan contents were greatest under full sun. It appears that growers of specialty crops serving the pharmaceutical industry can successfully establish and cultivate american mayapple under full sun, thus avoiding the cost of expensive shade structures, and provide leaf biomass with high podophyllotoxin content. In contrast to a destructive harvest of the entire plant - roots, rhizomes, and shoots-harvest of only the leafy portion allows for the mayapple crop to rejuvenate. As a result, the crop becomes a renewable source of plant material containing the compound of interest: podophyllotoxin. This research did not explore the effect of shade on growth or podophyllotoxin content of roots and rhizomes, and it is not known how lignan content of leaves corresponds to that of roots and rhizomes under increasing levels of shade.

\section{Literature cited}

Bedows, E. and G.M. Hatfield. 1982. An Investigation of the antiviral activity of Podophyllum peltatum. J. Natural Products 45:725-729.

Canel, C., R.M. Moraes, F.E. Dayan, and D. Ferreira. 2000a. Molecules of interest 'Podophyllotoxin' Phytochemistry 54:115-120.

Canel, C., F.E. Dayan, R.M. Moraes, and C. Burandt 2000b. Enhanced yield of podophyllotoxin from natural products through in situ conversion methods. US Patent 6, 143,304. Nov. 7, 2000.

Canel, C., F.E. Dayan, M. Ganzera, I.A. Khan, A. Rimando, C.L. Burandt, Jr., and R.M. Moraes 2001. High yield of podophyllotoxin from leaves of Podophyllum peltatum by in situ conversion of podophyllotoxin 4-O-B-D-glucopyranoside.
Planta Med. 67:97-99.

Craker, L.E., Z. Gardner and S.C. Etter. 2003. Herbs in American fields: A horticultural perspective of herb and medicinal plant production in the United States, 1903 to 2003. HortScience 38:977-983.

Davis, J.M. and J. McCoy. 2000. Commercial goldenseal cultivation. N.C. Coop. Ext. Serv. HIL-131. 18 June 2004. www.ces.ncsu.edu/ depts/hort/hil/hil-131.html

Demmig-Adams, B. and W.W. Adams, III. 1992. Carotenoid composition in sun and shade leaves of plants with different life forms. Plant, Cell and Environ. 15:411-419.

Foster, S. 1993. Medicinal plant conservation and genetic resources: Examples from the temperate northern hemisphere. Acta Hort. 330:67-73.

Foster, S. 2000. Black cohosh: Cimicifuga racemosa 18 June 2004. www.stevenfoster.com/education/monograph/bkcohosh.html.

Jackson, D.E. and P.M. Dewick. 1985. Tumor-inhibitory aryltetralin lignans from Podophyllum pleianthum. Phytochemistry 24:2407-2409.

Kelsey, R.G. and N.C. Vance. 1992. Taxol and cephalomannine concentrations in the foliage and bark of shade-grown and sun-exposed Taxus brevifolia trees. J. Nat. Prod. 55:912-917.

Lerndal, T. and B. Svensson. 2000. A clinical study of $\mathrm{CPH} 82$ vs. methotrexate in early rheumatoid arthritis. Rheumatology 39:316-320.

Maqbool,M., K.E. Cushman, R.M. Moraes, and P.D. Gerard. 2004. Overcoming dormancy of mayapple rhizome segments with low temperature exposure. HortScience 39:307-311.

Meijer,W. 1974. Podophyllumpeltatum-May apple a potential new cash-crop plant of eastern North America. Econ. Bot. 28:68-72.

Moraes, R.M., C. Burandt, Jr., M. Ganzera, X. Li, I. Khan, and C. Canel. 2000. The american mayapple revisited-Podophyllum peltatum-Still a potential cash crop? Econ. Bot. 54:471-476.

Pearce, D.K. and J.W. Thieret. 1993. Persimmon (Diospyros virginiana, Ebenaceae) and Mayapple (Podophyllum peltatum, Berberidaceae): Proximate analysis of their fruit. Trans. Ky. Acad. Sci. Louisville 54:30-31.

Persons, W. S. 1994. American ginseng: Green gold. Bright Mountain Books, Inc., Asheville, N.C.

Quigley, M.F. and S. Mulhall. 2002. The effects of shading in a greenhouse study on rhizome weight, root length, and bud proliferation in goldenseal. HortTechnology 12:717-720.

Rai, L.K., P. Prasad, and E. Sharma. 2000. Conservation threats to some important medicinal plants of the Sikkim Himalaya. Biol. Conserv. 93:27-33.

Schooley, J. 2003. Ginseng production in Ontario. Ontario Ministry of Agriculture and Food Ginseng series. 18 June 2004. www.gov.on.ca/ OMAFRA/english/crops/facts/gpak.htm.

Sinclair, A. and P.M. Catling. 2001. Cultivating the increasingly popular medicinal plant goldenseal: Review and update. Amer. J. Altern. Agr. 16:131-140. 